\title{
Usage Dynamics of Telecenters in São Paulo, Brazil'
}

\author{
Jeremiah Spence \\ Joseph Straubhaar
}


resumo: Este artigo, construído sobre a metodologia desenvolvida e apresentada por Straubhaar e Spence (2006), oferece uma análise introdutória sobre o programa Acessa São Paulo, uma iniciativa de inclusão digital do governo do Estado de São Paulo que, desde 2001, tem oferecido acesso livre a internet e a e-serviços governamentais através de parcerias locais com associações comunitárias, organizações governamentais e não governamentais. A pesquisa Ponline é um instrumento anual aplicado em 392 participantes de programas de telecentros que foram mapeados segundo hábitos e atitudes em relação a novas tecnologias e seus impactos pessoais e comunitários. Este artigo proporciona um quadro classificatório dos telecentros operados pelo Acessa São Paulo e utiliza uma extensa coleção de dados colhidos através de análise comparativa entre o Acessa São Paulo e projetos nacionais internacionais de inclusão digital.

Abstract: Building upon the methodology developed and presented in Straubhaar, Ferreira, e Spence (2006), this article presents an introductory analysis of the trends of the user base for the Acessa São Paulo Program (Acessa SP), a digital inclusion initiative of the government of the State of São Paulo (Brazil) that since 2001 has offered free access to the Internet and e-government services through local partnerships. Acessa SP currently, as of November 2006, funds and operates telecenters installed in partnerships with community associations, government-funded organizations and local governments. The Ponline research is an annual survey applied online in all the 392 participating telecenters in the program, which mapped and profiled the frequent users' habits and attitudes in relation to the new technologies and personal and community impacts. This article provides a of a framework for the classification of the telecenters operated by the Acessa SP program, and utilizes an extensive dataset collected through the annual Ponline telecenter user survey, which was presented in November 2006 to the government of the State of São Paulo. Building upon the conceptual framework of the previous work this article will allow for comparative analysis between the telecenters of the Acessa SP network and similar national and international projects, as well as, complimentary datasets.

SPENCE, Jeremiah; STRAUBHAAR, Joseph. Usage Dynamics of Telecenters in São Paulo, Brazil. Informática na Educação: teoria \& prática, Porto Alegre, v.10, n. 1, p.11-26, jan./jun. 2007. 
Building upon the methodology developed and presented in Straubhaar, Ferreira, e Spence (2006), this article presents an introductory analysis of the trends of the user base for the Acessa São Paulo Program (Acessa SP), a digital inclusion initiative of the government of the State of São Paulo (Brazil) that since 2001 has offered free access to the Internet and e-government services through local partnerships. Acessa SP currently, as of November 2006, funds and operates telecenters installed in partnerships with community associations, government-funded organizations and local governments.

\section{Digital Divide}

Even if information network (Castells, 2000), or postindustrial society (Bell, 1973) is denied by some as a theoretical framework (Garnham, 2004; Bolano, 2000, Robins \& Webster, 2004), the fact that new technologies of information and communication can increase the gap between rich and poor is undeniable. We should refer to this gap, as the digital divide or in the Brazilian context - inclusão digital. The new information and communication technologies (ICTs or TICs) are pervasive in the entirety of society and the risk of being left behind prompt governments and non-governmental organizations (NGOs) to set initiatives aimed at overcoming the gap between those who have access to technology and who are excluded of it. UNESCO (United Nations Educational, Science and Cultural Organization), the ITU (International Telecommunications Union) and the WSIS (World Society on the Information Society) have all called for increasing the resources applied to making ICTs more accessible in developing countries. Telecenters continue to be one of the strategies most encouraged, as was notable a recent UNESCO bulletin on the Information Society (10/20/06).
Strover (2004) defines telecenters as "a popular designation for sites where people can go for a variety of telecommunication services, from local and long distance phone calling to computer and Internet access and training." ( $p$. 466). She concludes that the aim of those telecenters, specifically in the U.S. case, is to expand access to computers and Internet to those who do not have it. Starting in the Clinton government, both the Federal government, through the Departments of Commerce and Education, as well as the FCC (Federal Communications Commission), and several states, including Texas, created programs to fund the creation and development of telecenters, add computers to public libraries, and subsidize the required telecommunications connectivity costs (through the FCC e-Rate program).

Strover, et al, (2004) criticizes the technological optimism that believes on the fact that the simple provision of computers will develop communities and generate their wellbeing. According to her, the attempt to overcome the digital divide through the simple provision of access is a mistake and a simple answer to a complex problem. What is necessary is to give communities the opportunity to articulate their own use of the technology provided. The U.S. Department of Education in particular recognized this need and funded programs for training people in computer use. The program was somewhat biased toward office computer use, teaching skills such as spreadsheets and word processing. An evaluation of one program in Austin by Tufekci, Straubhaar and Strover (2002) showed that few working class or minority people got office jobs because of this training. However, the same evaluation showed that quite a few people in these training programs benefited greatly from both computer and 
internet skills in various aspects of their lives, particularly the Internet skills which were a very minor part of the training.

Fuentes, Rojas, Straubhaar and Spence (2005) have examined strategies for increasing people's capacities for learning more skills and acquiring the knowledge required for effective computer use. Their work builds on Amartya Sens' concept of capacity building, which urges a very broad view of increasing human capacities for learning knowledge, attitudes and skills. They also build on Bourdieu's (1984) ideas of building cultural capital, which they find is required to effectively use the Internet or computer technology. They also build on his idea that changing people's dispositions to use such technologies is a closely related capacity.

\section{Internet in Brazil}

Having arrived in Brazil in 1988, supported by an initiative of the Foundation for Support of Research for the State of São Paulo $\left(\right.$ FAPESP) ${ }^{2}$, the Internet was initially exclusively made available for educational institutions, research institutes and government offices in 1991. Commercial access and use of the Internet began in 1995 when the first Internet providers started up. From there on the Internet has had accelerated growth in Brazil, but that expansion has largely been homogenous, limited largely to the richest areas of the country.

According to IIZUKA (2003),

In Brazil, according to the Brazilian Census Bureau (IBGE) ${ }^{3}$, in 2000 there were 10 to 20 users of informatics in every 100,000 inhabitants. The Southeast region concentrates $58 \%$ of the Internet access providers, with $12 \%$ in the City of São Paulo and $8 \%$ in Rio de Janeiro. In only $6 \%$ of Brazilian counties (5.500 in total), in only 300 cities, is there the minimum infrastructure necessary for installing local Internet access services.
Which is to say, parallel to the expansion of the Internet and the new technologies, Brazil also saw the formation and development of a preoccupying digital divide. According to IIZUKA (2003),

According to the OECD (2001), digital exclusion refers to gaps between individuals, families, companies, geographic regions and different socioeconomic levels with respect to, simultaneously, their opportunities for access to the information and communication technologies (ICTs) and the use of the Internet for a wide variety of actions and activities.

Economic class or purchasing power seems to have been a key factor in determining who has access to the internet. In 2002, a study by the NetRatings Audience Institute, which showed that there were 7.68 million Brazilian Internet users, but that $85 \%$ of them belonged to class A (the top $2-4 \%$ ), and only $2 \%$ belonged to classes D and $\mathrm{E}$ (the bottom 60\%).

\section{Initiatives by the Government of the State of São Paulo}

To combat digital exclusion, various global and Brazilian initiatives in digital inclusion were taken. In this context, in November 2000, the first telecenter of the São Paulo Access program, a digital divide initiative of the government of the State of São Paulo, with the goal of creating 123 centers in two years, in regions inhabited by populations of low purchasing power (classes D and E).

According to LITTO (2001), a telecenter of Acessa SP "is a physical space, of easy public access, which offers free services in informatics and telecommunications, in a context of social, economic, educational and personal development. Its conception is based in the belief that the citizen has his/her power augmented when they have access to knowledge". 
In accordance with this conception, then, the program Access São Paulo developed a strategy of appropriation and use of these telecenters. According to GUZZI (2002):

The Internet can have very different uses and effects, depending on where it is used and into what context it is inserted. One can imagine that in public locales for access, the telecenters, its use will be different. Even though to elaborate use strategies, you must consider the context, the rules of use, the time permitted for access, the people trained to orient users, the services offered, the proposed activities and the local necessities. Furthermore, you should take into account the different publics that demand different strategies. The appropriation of these structures for the community depends fundamentally on the attention offered to the users. For people who have never had any contact with a computer, the availability and attention of a trained professional are indispensable. The more that the user feels welcomed or comfortable and secure or safe to explore and use the resources of the Internet, the more they will frequent a telecenter.

The strategy developed for Acessa SP seeks to promote the effective use of the technology by the users and communities. Acessa SP has operated an increasing number of telecenters (now 392) for the state since 2001. In 2006, 53 of their centers (14\%) were partnerships with community organizations, primarily in poor urban neighborhoods; 288 (74\%) were partnerships with city governments, particularly in small interior or coastal towns of the state; and 51 (13\%) were access posts in various community-oriented facilities of the City of São Paulo (Guzzi 2006).

Annually, LIDEC, a research group at the University of Sao Paulo's School of the Future, carried out an online research project in all the telecenters participating in the Acessa SP program, which developed a profile of frequent users, their habits and attitudes in relation to the new technologies and the relative personal and community impacts of those technologies, called PONLINE. In October of 2006, after five and a half years since its inauguration, the Acessa Sao Paulo program had more than 900,000 registered users and had 19 million halfhour sessions accessed. There are currently 386 telecenters installed throughout the state.

\section{Classifying the Telecenter}

The establishment of a functional and efficient framework for the analysis and efficient management of the Acessa Sao Paulo telecenter's user data, as obtained from the Ponline user survey, is essential for researchers to have the capacity to understand and analyze the intricacies of the user experience, and/or strive to amplify the impact of the telecenters on the various publics that they serve. This objective has been part of the guidelines utilized by the LIDEC research team since the initiation of the Acessa Sao Paulo research project. In order for this framework to function to the greatest degree possible this paper proposes a reorientation of the classification system from one based on the origin of the center (i.e. Comunitários, Municipais and POPAls) to a system based on the user experience. This reorientation provides a strong complementary approach that will facilitate more in-depth and efficient analysis of both the telecenters and the user experience at the telecenter. This reorientation of the classification system will provide, for example, that libraries currently classified as municipal or comunitário will now be classified as solely libraries, so that the experience of a telecenters in a library can be the focus of comparative analysis. Further, the reorientation of the classification will fundamental improve and expand upon the way that the data collected from the PONLINE survey is analyzed and processed. 
A greater degree of insight will be available to researchers, center managers, and policy makers that will hopefully be combined to create a fuller and more worthwhile experience for the end-user.

While these categories are initially descriptive they provide a conceptual starting point for a more precise understanding and analysis of both the telecenters and the users that utilize these telecenters in their daily lives. Further, these categories provide a sufficient conceptual structure to allow for comparative analysis between the Acessa Sao Paulo network and other digital divide projects, both in Brazil and beyond. Many of the research projects that have been published are oriented towards a specific category that is represented here, libraries or public schools, for example. This development both builds upon the pre-existing foundation established by the Acessa Sao Paulo and reinforces the goals of the program by elaborating a more precise context for the understanding of the telecenters and their users.

The eight categories that follow are based not upon legal, financial or institution origin, but rather what type of experience a user would have when visiting the various centers. This of course brings about a number of interesting juxtapositions that must be reconciled. The first four of the categories are fairly simple:

- Libraries

- Public Transit Stations

- Other types of space (Churches, Shopping Centers, and Tourism Centers)

- Unclassifiable Spaces

The first category - "libraries" represents, in the first sample, twenty-four percent of the total telecenters population. This runs contrary to the study by Straubhaar, et al, (2006), which, among other things, noted the historical absence of public libraries as a significant actor in the development of responses to the digital divide in Brazil, particularly in the context of Salvador. However, in the specific cases of both the city of Sao Paulo and the state of Sao Paulo the investment of public funds in the development and expansion of public libraries has far outpaced other locales in Brazil. Additionally, the state of Sao Paulo, in the implementation of the Acesso Sao Paulo network, has chosen to include libraries as a key component of its efforts to build and implement responses to the digital divide. Finally, separating libraries from the general population of telecenters will allow for significant comparative analysis with efforts in the United States, as many of the projects developed in the United States over the past ten years are located in public libraries. These classifications will allow for both a comparative analysis between models in the Sao Paulo context and between like models both in and outside of Sao Paulo. For example, the library model of implementing telecenters in Sao Paulo can be compared to similar telecenter models in Europe and the United States.

The second category - "public transit stations" represents six percent of the sample in the initial analysis. Although it is numerically a fairly small group of telecenters, public transit stations represent both a fairly simple conceptual differentiation and a space that has a fairly significant community, as a large portion of the population living in the Greater Sao Paulo area depends on public transit for their day to day subsistence. Finally, the experience of utilizing public access to access the internet in a public transit station is a fairly specific one that needs to be explored and analyzed further by this research group. 
The third category - "other types of space" is actually an aggregation of three numerically smaller categories: churches, shopping centers, and tourism centers. Although this aggregation of categories only represents two percent of the total telecenters examined in this paper, it is a conceptually significant distinction because there are a number of published studies on user experiences in churches, shopping centers and tourism centers already available for comparative analysis.

The fourth category - "unclassifiable spaces" refers to the eighteen percent of the examined telecenters that were unable to be classified, primarily because the authors of this paper were unable to establish direct contact with the centers or the center managers to gain more detailed information on the location and profile of the center. This, of course, is a statistically significant number especially when examined from the perspective of the PONLINE survey where eighteen percent of the survey population (total $=8113$ completed surveys) potentially represents 1460 users.

The second set of categories requires more in-depth analysis because they represent a series of conceptual innovations that have taken place in the technological and social environment of Sao Paulo in relation to responses to the digital and these categories are part of an effort to provide a framework that will allow for the examination and analysis of these innovations. However, due to the nature of these centers and the length restrictions of this paper, the authors have chosen to only superficially examine these centers in this paper and prepare a

\section{Graph 1- Distribution of Access SP Telecenters by Classification. Sao Paulo, Brazil - November 2006}

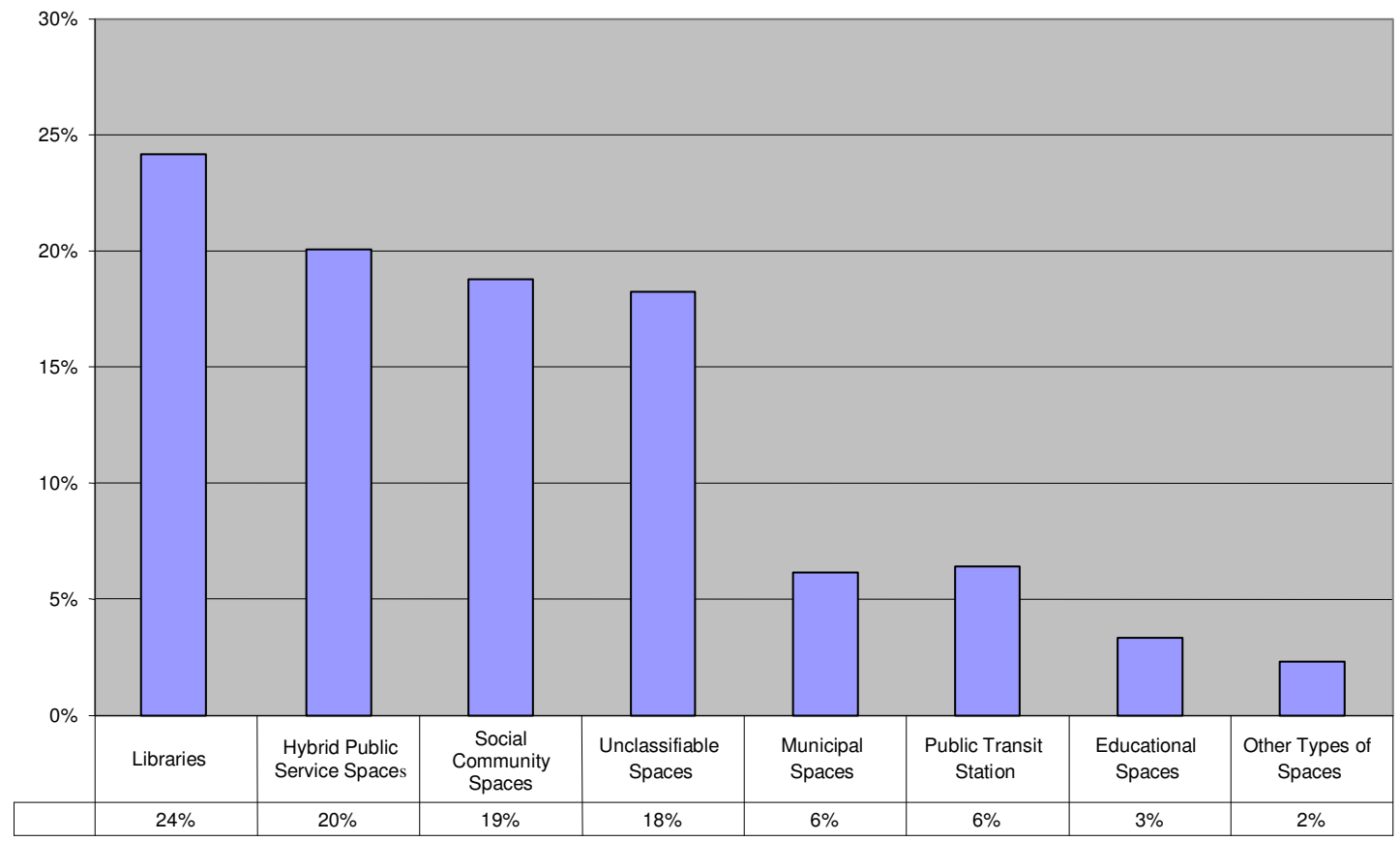

Source: PONLINE survey, 2006. 
more in-depth analysis of each category for a series of research papers to follow. The second group of categories are:

- Hybrid Public Service Spaces

- Social Community Spaces

- Municipal Space

- Educational Spaces

The fifth category - hybrid public service spaces is a category being proposed and presented for the first time in this paper and refers to a series of initiatives developed in the Sao Paulo social and technological sphere that provide a public space where the user can interact with a multitude of federal, state, and municipal government services along with, depending on the center, non-profit organizations and university-run community initiatives all in the same building or series of buildings. All of the centers that have been classified as hybrid public service spaces provide an Acessa Sao Paulo telecenter with free access to the internet in a shared space with other public services, either governmental or non-governmental. This category represents twenty percent of the total telecenters examined for this paper. This category has been broken down into three subcategories based on the type of services that a user would encounter in these spaces: governmental, non-governmental and mixed. Governmental only spaces would include the Poupa Tempo model, popular in the city of Sao Paulo, (Annenberg 2002) and a similar initiative called CIC or Centro de Integração e Cidadania, which is more readily available in the interior of the state of Sao Paulo. Spaces that are more oriented, although not exclusively, towards providing non-governmental services includes, for example, the Estação Especial da Lapa, which is a refurbished train station that provides a telecenter operated by Acessa Sao Paulo; a science museum operated by the University of Sao Paulo; a outreach program targeting young street children by providing access to technology and training in an unstructured manner called Projeto Clicar - operated by a non-governmental organization in partnership with the University of Sao Paulo; a training center operated by CENAI - government-funded non-profit organization; and space for the care of people in wheelchairs. Along with all of these services being provided inside the Estação Especial da Lapa, there is located a busy transit station and a municipal market place along popular restaurants all within one city block of the Estação Especial da Lapa. Interestingly, the development of spaces that integrated access to the internet with a number of other services provided by multiple state and non-state actors is a phenomenon that has been replicated throughout the State of Sao Paulo.

The sixth category - "Social Community Spaces" refers to the co-location of Acessa Sao Paulo telecenters within spaces operated by non-governmental organizations (NGO) or organização não governamental (ONG) and represents nineteen percent of the total telecenters examined in this paper. The broad category of social community spaces provides a suitable framework for categorizing a certain type of user experience, usually in a smaller space defined by a single type of activity, but does not refer solely to organizations that receive no government funding. This is noteworthy, as some of the initiatives such at the "Bom Prato" (Castro 2004) or popular restaurant sub-category receives significant government funding; however, the experience that a user would encounter in using a telecenter in a "Bom Prato" is similar to that of other locales classified as social community spaces.

"Social community spaces" has been broken down into eight categories; some 


\section{INFORMÁTICA NA EDUGAĈ̣̃O:}

teoria \& prática Porto Alegre, v.10, n.1, jan./jun. 2007. ISSN 1516-084X

categories are descriptive while others are purely conceptual. Due to the number of categories and the multitude of different initiatives within the "social community space" category it is essential that these initiatives be examined in greater detail in the following paper.

The sub-categories within the "social community space" area are:

- Cultural Centers - A cultural center is an architecturally contemporary space destined and present for cultural shows of the most diverse modalities. (Wiki 2006)

- Creches - A creche is a space administered by a specific government entity (in the Brazilian case, state or municipal), nongovernmental entity, or, as well, a space inside of a private company where parents can leave their children (usually ages $0-10$ years) while they work. These spaces exist for people who do not have whom to leave their children, such as relatives or stay-at-home nannies. [Interestingly,] the Brazilian Constitution of 1988 defined access to day care as a right of Brazilian citizens. (Wiki 2006)

- Neighborhood Associations

- Banco do Povo - Micro-credit banks for small investors and small investments.

- Popular Restaurant / "Bom Prato"Community restaurants built by the government and designed to provide subsidized meals to promote the well-being of the working poor.

- Samba Schools

- Sports Center

- Unclassifiable

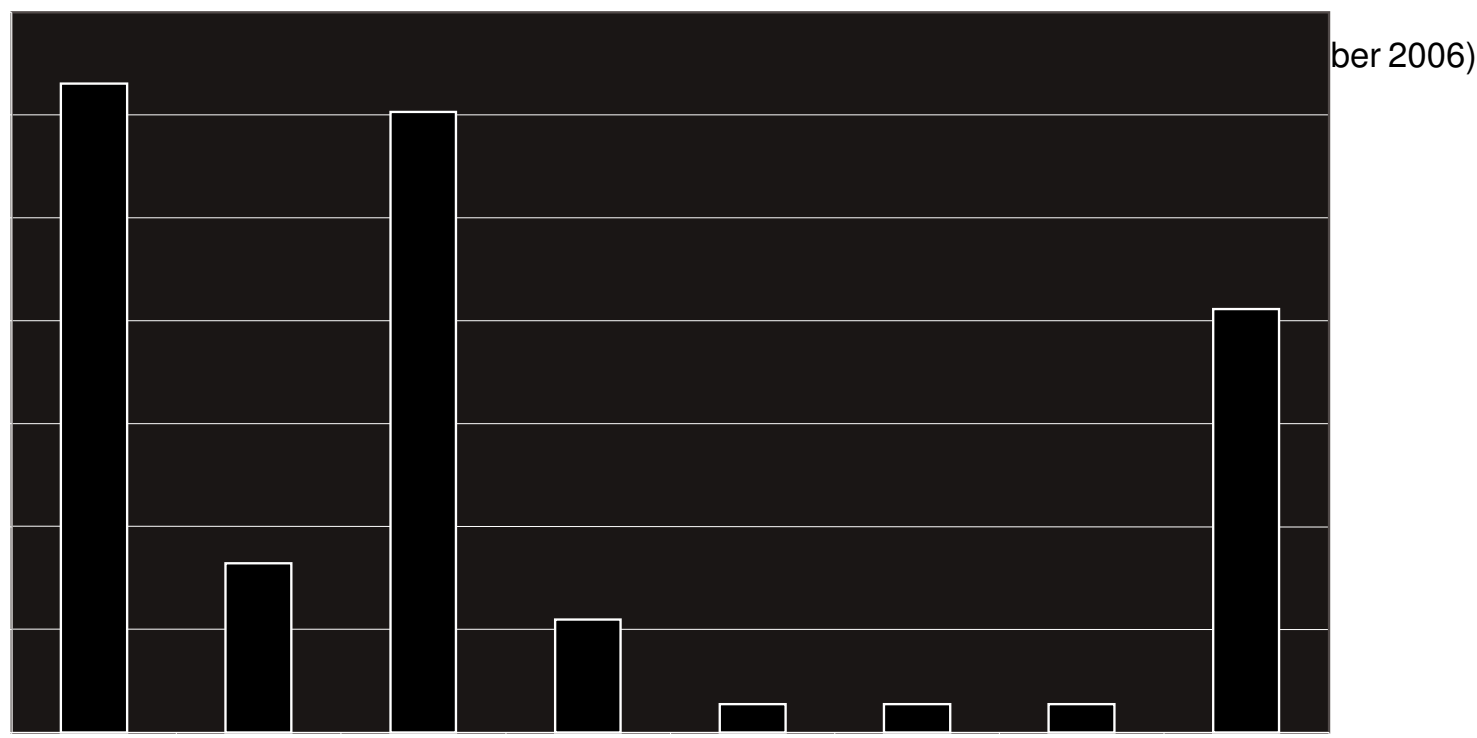

Source: PONLINE survey, 2006. 
The seventh category - "municipal spaces" refers to the telecenters that are located with city halls and similar exclusively government spaces. This category represents six percent of the total centers in the sample examined for this paper. It is possible that upon more focused examination of some of the centers currently classified as municipal spaces they may indeed be more appropriately classified as hybrid public service spaces depending on the specifics of what type of experience a user would encounter when entering the telecenter. This, of course, is something that will need to be determined though more detailed examination of the centers on an individual basis.

The eighth category - "educational spaces" refers to the three sub-categories of public schools, technical schools and several types of educational centers. This category represents three percent of the total centers in the sample examined for this paper. Although numerically small, this category, especially the public schools sub-category, will also allow for the comparative analysis of the experiences of the users in the Sao Paulo context with other published studies in other countries.

\section{User profiles of the different kinds of centers}

The different kinds of centers attract substantially different kinds of users, as the following tables will show. This illuminates a significant pattern, which can help us understand what kinds of centers might best attract and serve different kinds of users. To reach lower income users, for example, the State of Sao Paulo may wish to put in more of the kinds of centers that attract low income users. These profiles also indicate which kinds of centers might have to take some new initiatives to make themselves more attractive or open to certain kinds of users
These profiles are based on a survey of 8,117 users of the telecenters described above in the State of Sao Paulo. They were a sample taken by skip intervals among user lists from a total set of roughly 20,000 users active in a given week. Those in turn represent over 1 million registered users, although we must assume that active users are different from those who have registered, but were not actively using the centers during the week the survey was taken. Although we cannot know exactly how they are different, this sample of users is compellingly large and represents all the different kinds of centers and users in which we are interested. The following analyses are based on crosstabulations. All of the cross tabs below are significant at the $\mathrm{P}=.001$ level.

One of the key social distinctions in Brazil, and elsewhere, is social class. Brazil is highly stratified in terms of class. As noted above, the top three classes, A (elite - top 2$3 \%$ ), B (upper middle - next 5-7\%) and C (middle class - next $20-25 \%$ ), only make up $30-40 \%$ of Brazil's population, while the working class (D) or poor (E) make up $60-70 \%$. There is relatively little social mobility and the digital divide was widely feared to widen these existing social stratifications even further by giving a very useful new set of ICT tools to those who are already best advantaged, while pushing the poor even further behind in relative terms.

One of the fundamental dimensions of that is economic capital or income. In terms of family income, for example, we see below in Table One, that certain kinds of centers are significantly more likely to attract lower income people. Libraries, concentrated spaces for the delivery of services, public transit space spaces, and other spaces are more likely to have lower income users, those making less than $\$ 1000$ a month, than are educational spaces, city 
Table 1 - Family Income (in reias) by Types of Telecenter Spaces - Sao Paulo, Brazil November 2006

\begin{tabular}{|l|r|r|r|r|r|r|r|}
\hline & \multicolumn{7}{|c|}{ Family Income } \\
\cline { 2 - 8 } Spaces & $\begin{array}{c}\text { More } \\
\text { than } \\
\mathrm{R} \$ 2000 \\
\mathrm{a} \text { month }\end{array}$ & $\begin{array}{c}\text { From } \mathrm{R} \$ 1500 \\
\text { to } \\
\mathrm{R} \$ 2000\end{array}$ & $\begin{array}{c}\text { From } \mathrm{R} \$ 1000 \\
\text { to } \\
\mathrm{R} \$ 1500\end{array}$ & $\begin{array}{c}\text { From } \\
\mathrm{R} \$ 700 \text { to } \\
\mathrm{R} \$ 1000\end{array}$ & $\begin{array}{c}\text { From } \\
\mathrm{R} \$ 350 \text { to } \\
\mathrm{R} \$ 700\end{array}$ & $\begin{array}{c}\text { From } \\
\mathrm{R} \$ 150 \text { to } \\
\mathrm{R} \$ 350\end{array}$ & $\begin{array}{c}\text { Less } \\
\text { than } \\
\mathrm{R} \$ 150 \mathrm{a} \\
\text { month }\end{array}$ \\
\hline Libraries & $1 \%$ & $1 \%$ & $3 \%$ & $12 \%$ & $31 \%$ & $38 \%$ & $13 \%$ \\
\hline $\begin{array}{l}\text { Educational } \\
\text { spaces }\end{array}$ & $2 \%$ & $0 \%$ & $1 \%$ & $5 \%$ & $31 \%$ & $40 \%$ & $21 \%$ \\
\hline $\begin{array}{l}\text { Hybrid public } \\
\text { service space }\end{array}$ & $2 \%$ & $2 \%$ & $4 \%$ & $12 \%$ & $30 \%$ & $35 \%$ & $14 \%$ \\
\hline $\begin{array}{l}\text { Community social } \\
\text { spaces }\end{array}$ & $1 \%$ & $1 \%$ & $2 \%$ & $7 \%$ & $28 \%$ & $43 \%$ & $18 \%$ \\
\hline $\begin{array}{l}\text { Public transit } \\
\text { stations }\end{array}$ & $2 \%$ & $2 \%$ & $4 \%$ & $13 \%$ & $36 \%$ & $33 \%$ & $10 \%$ \\
\hline $\begin{array}{l}\text { Other types of } \\
\text { spaces }\end{array}$ & $3 \%$ & $3 \%$ & $4 \%$ & $13 \%$ & $25 \%$ & $37 \%$ & $14 \%$ \\
\hline City spaces & $2 \%$ & $3 \%$ & $3 \%$ & $8 \%$ & $29 \%$ & $37 \%$ & $20 \%$ \\
\hline
\end{tabular}

Source: PONLINE survey, 2006.

\begin{tabular}{|c|c|c|c|c|c|c|}
\hline \multirow[b]{2}{*}{ Spaces } & \multicolumn{6}{|c|}{ Level of Education } \\
\hline & $\begin{array}{l}\text { Pre-school } \\
\text { Table } 2\end{array}$ & $\begin{array}{l}\text { Elementary } \\
\text { / Middle } \\
\text { - Lgyedof E }\end{array}$ & $\begin{array}{c}\text { High } \\
\text { Edueattroth by }\end{array}$ & $\begin{array}{c}\text { Technical } \\
\text { Týpiesingf Th }\end{array}$ & $\begin{array}{c}\text { Higher } \\
\text { elédentiens }\end{array}$ & $\begin{array}{c}\text { Graduate } \\
\text { paéestisatisao }\end{array}$ \\
\hline Libraries & $0 \%$ & $26 \%$ & $53 \%$ & $\begin{array}{c}\text { November } \\
7 \%\end{array}$ & $\begin{array}{r}2006 \\
12 \%\end{array}$ & $1 \%$ \\
\hline $\begin{array}{l}\text { Educational } \\
\text { spaces }\end{array}$ & $1 \%$ & $38 \%$ & $44 \%$ & $3 \%$ & $12 \%$ & $2 \%$ \\
\hline $\begin{array}{l}\text { Hybrid public } \\
\text { service space }\end{array}$ & $0 \%$ & $14 \%$ & $56 \%$ & $9 \%$ & $17 \%$ & $3 \%$ \\
\hline $\begin{array}{l}\text { Community social } \\
\text { spaces }\end{array}$ & $1 \%$ & $28 \%$ & $59 \%$ & $4 \%$ & $6 \%$ & $1 \%$ \\
\hline $\begin{array}{l}\text { Public transit } \\
\text { stations }\end{array}$ & $1 \%$ & $12 \%$ & $58 \%$ & $11 \%$ & $16 \%$ & $2 \%$ \\
\hline $\begin{array}{l}\text { Other types of } \\
\text { spaces }\end{array}$ & $0 \%$ & $10 \%$ & $66 \%$ & $10 \%$ & $13 \%$ & $2 \%$ \\
\hline City spaces & $1 \%$ & $34 \%$ & $54 \%$ & $4 \%$ & $5 \%$ & $1 \%$ \\
\hline
\end{tabular}


government spaces, and community organization spaces.

In another key aspect of social class, we need to examine user profiles in terms of education, which often equates to Bourdieu's concept of cultural capital (1984). Again, in table two below, we see that different kinds of centers have very different profiles in terms of the educational levels of their users. Educational spaces were much less likely to have users with high school education or less, while other kinds of centers where more likely to have less educated users.

Table 3 - Age Range by Types of Telecenter Spaces - Sao Paulo, Brazil - November 2006

\begin{tabular}{|l|c|c|c|c|c|c|c|c|}
\hline \multirow{2}{*}{ Spaces } & \multicolumn{7}{|c|}{ Age Range } \\
\cline { 2 - 9 } & $\begin{array}{c}\text { ate 14 } \\
\text { anos }\end{array}$ & $\begin{array}{c}15-19 \\
\text { anos }\end{array}$ & $\begin{array}{c}20-24 \\
\text { anos }\end{array}$ & $\begin{array}{c}25-29 \\
\text { anos }\end{array}$ & $\begin{array}{c}30-39 \\
\text { anos }\end{array}$ & $\begin{array}{c}40-49 \\
\text { anos }\end{array}$ & $\begin{array}{c}50-59 \\
\text { anos }\end{array}$ & $\begin{array}{c}\text { mais de } \\
60 \text { anos }\end{array}$ \\
\hline Libraries & $18 \%$ & $42 \%$ & $17 \%$ & $9 \%$ & $8 \%$ & $4 \%$ & $1 \%$ & $0 \%$ \\
\hline $\begin{array}{l}\text { Educational } \\
\text { spaces }\end{array}$ & $30 \%$ & $37 \%$ & $14 \%$ & $6 \%$ & $9 \%$ & $2 \%$ & $2 \%$ & $0 \%$ \\
\hline $\begin{array}{l}\text { Hybrid } \\
\text { public } \\
\text { service } \\
\text { space }\end{array}$ & $7 \%$ & $28 \%$ & $24 \%$ & $14 \%$ & $16 \%$ & $8 \%$ & $2 \%$ & $0 \%$ \\
\hline $\begin{array}{l}\text { Community } \\
\text { social } \\
\text { spaces }\end{array}$ & $18 \%$ & $46 \%$ & $19 \%$ & $7 \%$ & $6 \%$ & $2 \%$ & $1 \%$ & $0 \%$ \\
\hline $\begin{array}{l}\text { Public } \\
\text { transit } \\
\text { stations }\end{array}$ & $5 \%$ & $32 \%$ & $28 \%$ & $15 \%$ & $15 \%$ & $4 \%$ & $1 \%$ & $0 \%$ \\
\hline $\begin{array}{l}\text { Other types } \\
\text { of spaces }\end{array}$ & $5 \%$ & $36 \%$ & $28 \%$ & $12 \%$ & $12 \%$ & $3 \%$ & $3 \%$ & $1 \%$ \\
\hline City spaces & $23 \%$ & $45 \%$ & $19 \%$ & $5 \%$ & $4 \%$ & $2 \%$ & $1 \%$ & $0 \%$ \\
\hline
\end{tabular}

Source: PONLINE survey, 2006.

The age range of different centers likewise varies (Table 3). Concentrated spaces for the delivery of services, public transit spaces, and other kinds of spaces were more likely to attract older users. In contrast, libraries, educational spaces, community spaces and city spaces were more likely to have a younger clientele, which is typical of most telecenters. Additionally, it is interesting that a few kinds of spaces are more capable of drawing in or attracting adult users.
Gender also makes a considerable impact of the user profile of different kinds of telecenters (Table 4). Libraries, educational spaces, and public transit spaces were most likely to attract women as users, which is notable since Brazilian telecenters are still dominated by male users. So it is interesting to know which kinds of spaces are more comfortable or attractive to women. 
Table 4 - Gender by Types of Telecenter Spaces - Sao Paulo, Brazil - November 2006

\begin{tabular}{|l|c|c|}
\hline \multirow{2}{*}{ Spaces } & \multicolumn{2}{|c|}{ Gender } \\
\cline { 2 - 3 } & Female & Male \\
\hline Libraries & $41 \%$ & $59 \%$ \\
\hline Educational spaces & $41 \%$ & $59 \%$ \\
\hline Hybrid public service space & $34 \%$ & $66 \%$ \\
\hline Community social spaces & $37 \%$ & $63 \%$ \\
\hline Public transit stations & $38 \%$ & $62 \%$ \\
\hline Other types of spaces & $32 \%$ & $68 \%$ \\
\hline City spaces & $39 \%$ & $61 \%$ \\
\hline
\end{tabular}

Source: PONLINE survey, 2006.

A final difference that is key to understanding use of telecenters is their very different profiles in terms of the race of their users. Almost 60 percent of Brazilians are AfroDescendent (Black) or mixed (mulatto in the official census categories used in this study. However, the racial divide in Brazil is extreme, since Black and mixed race Brazilians are also heavily concentrated among the poorest in Brazil. It is notable that libraries and educational spaces are most dominated by Whites, while more Black and mixed users show up at hybrid public service space, community centers, public transit spaces, and other spaces.

Table 5 - Race by Types of Telecenter Spaces - Sao Paulo, Brazil - November 2006

\begin{tabular}{|l|c|c|c|c|c|c|}
\hline \multirow{2}{*}{ Spaces } & \multicolumn{6}{|c|}{ Race } \\
\cline { 2 - 7 } & Asian & White & Indigenous & Mulatto & Black & Other \\
\hline Libraries & $3 \%$ & $60 \%$ & $1 \%$ & $27 \%$ & $7 \%$ & $2 \%$ \\
\hline $\begin{array}{l}\text { Educational } \\
\text { spaces }\end{array}$ & $1 \%$ & $60 \%$ & $3 \%$ & $27 \%$ & $7 \%$ & $2 \%$ \\
\hline $\begin{array}{l}\text { Hybrid public } \\
\text { service space }\end{array}$ & $2 \%$ & $49 \%$ & $2 \%$ & $30 \%$ & $13 \%$ & $4 \%$ \\
\hline $\begin{array}{l}\text { Community } \\
\text { social spaces }\end{array}$ & $2 \%$ & $42 \%$ & $2 \%$ & $35 \%$ & $16 \%$ & $3 \%$ \\
\hline $\begin{array}{l}\text { Public transit } \\
\text { stations }\end{array}$ & $3 \%$ & $46 \%$ & $2 \%$ & $33 \%$ & $12 \%$ & $4 \%$ \\
\hline $\begin{array}{l}\text { Other types of } \\
\text { spaces }\end{array}$ & $0 \%$ & $49 \%$ & $3 \%$ & $31 \%$ & $13 \%$ & $4 \%$ \\
\hline City spaces & $3 \%$ & $52 \%$ & $2 \%$ & $32 \%$ & $8 \%$ & $4 \%$ \\
\hline
\end{tabular}

Source: PONLINE survey, 2006. 


\section{Conclusion}

This analysis, utilizing the data collected through the 2006 Ponline user survey, found significant differences among the users of various kinds of centers, which indicates that some kinds of centers are more able at this point to attract the lower income, minority and least advantaged users that the telecenter program targets. Depending on the disadvantaged group in question, the most effective or at least most widely used centers are those associated with hybrid public service spaces, public transit spaces, and community center spaces.
As the State of Sao Paulo expands it's the digital inclusion program, it is essential to understand the telecenters' general social impact. This is possible, in part, by analyzing the user's profiles, their habits and their attitudes regarding the new technologies - especially among those users who only have public access to the Internet through telecenters. The next step in this analysis is to compare the impact of the Sao Paulo telecenter network with other regional networks.

\section{References}

Annenberg, Daniel (2002). "Diretrizes e estratégias para a implantação e manutenção de um padrão de qualidade na prestação de serviços públicos: a experiência paulista do Poupatempo". Lisboa, Portugal. VII Congreso Internacional del CLAD sobre la Reforma del Estado y de la Administración Pública. 8 - 11 Oct. 2002. <http://www.iij.derecho.ucr.ac.cr/docs_bd/pub\%20otras\%20entidades/CLAD/CLAD\%20VII/ DOCUMENTOS/ANNENBER.PDF>.

Bell, D. (1973). The coming of post-industrial society: A venture in social forecasting (First ed.). United States: Basic Books.

Bolano, César Ricardo Siqueira. (2000) Políticas de Comunicação e Economia Política das Telecomunicações no Brasil: Convergência, Regionalização e Reforma. ARACAJU- SE:2000.

Brasil. (2000) Ministerio da Ciencia e da Tecnologia. Sociedade da Informacao no Brasil: Livro Verde. Brazilia, DF, 2000

Bourdieu, P. (1984). Distinction: A social critique of the judgement of taste. London: Routledge.

Castells, M. (2000). The rise of the network society (2nd ed. Vol. 1): Blackwell Publishing.

Castro, Maria Helena Guimarães de. (2004) A política de combate à pobreza do governo do estado de São Paulo. São Paulo Perspec., Oct./Dec. 2004, vol.18, no.4, p.3-7. ISSN 0102-8839.

Ferreira, F. (2004) O Brazil na Sociedade da Informação: Estado regulador e Agencia Nacional de Telecomunicacoes. Dissertacao de Mestrado. UFBA, 2004

Garnham, N. (2004). Information society theory as ideology. In F. e. Webster (Ed.), The information society reader (pp. 165-183). London: Routledge.

Guzzi, Adriana de Araujo. (2002) Tendências do uso da Internet em locais públicos. Preparado para o fim do Primeiro Ciclo do Programa Acessa São Paulo. Laboratório de Inclusão Digital e Educação Comunitária da Escola do Futuro USP, São Paulo, 2002. Junho de 2002. Disponível em: <http:// www.lidec.futuro.usp.br/downloads/artigo-drica.pdf>. Acesso em: 01 ago. 2006.

Guzzi, Adriana de Araujo. (2005) Participação pública, comunicação e inclusão digital. 2005. 140f. Dissertação (Mestre) - Pontifica Universidade Católica - SP, Sao Paulo. Disponível em: <http:// www.lidec.futuro.usp.br/downloads/drica-mestrado-tese-somente.pdf>. Acesso em: 05 out. 2006. 
lizuka, Edson Sadão. (2003) Um estudo exploratório sobre a exclusão digital e as organizações sem fins lucrativos da cidade de São Paulo. 2003. 163f. Dissertação (Mestrado em Administração Pública e Governo) - Fundação Getúlio Vargas - Escola de Administração de Empresas de São Paulo), São Paulo, 2003.

Laboratorio de Inclusao Digital e Educacao Comunitaria. (2006) Portal LIDEC. Disponível em: <http:// www.lidec.futuro.usp.br>. Acesso em: 01 ago. 2006.

Litto, Fredric M. (2001). "Educação Inflexível e Tutelada”, Correio Brazilense (Brasília), August 15; p.2.; "O MEC é um Obstáculo Formidável para a Educação à Distância no País", O Globo (Rio de Janeiro), October 8, 2001.

Litto, Fredric M. (2006) Telecentros Comunitários — Uma Resposta à "Exclusão Digital. Disponível em: <http://www2.uol.com.br/aprendiz/n_colunas/f_litto/id211100.htm>. Acesso em: 01 ago. 2006.

Matielo, Daniela de Carvalho. (2006) Digital: a não neutralidade das novas tecnologias, dos jogos à política. Disponível em: < http://www.lidec.futuro.usp.br/downloads/digital_dani.pdf>. Acesso em: 01 ago. 2006.

OECD Report 2001. (2001). Drivers of growth: information technology, innovation and entrepreneurship. Disponível em: <http:www1.oecd.org/publications/e-book/9201131e.pdf> Acesso em: 10 out. 2006.

Programa Acessa Sao Paulo. (2006) Portal AccessSP. Disponível em: <http://www.acessasp.sp.gov.br>. Acesso em: 01 ago. 2006.

Roman, Raul. (2004) Diffusion of Innovation as a Theoretical Framework for Telecenters. MIT Information Technologies and International Development, Winter 2003. 2004, vol.1, no.2, p.53 -66.

Robins, K., \& Webster, F. (2004). The long history of the information revolution. In F. e. Webster (Ed.), The information society reader (pp. 62-80). London: Routledge.

Strover, S. (2004) Beyond community networking and CTCs: access, development, and public policy. Telecommunications Policy. v.28, April 2004, 465-485

Straubhaar, J.; Ferreira, F.; Spence, J. (2006). "Comparing Government and NGO Digital Inclusion Initiatives in the U.S. and Brazil". Washington DC. Telecommunications Policy Research Conference (TPRC) 2006.

Straubhaar, J., Fuentes, M., and Spence, J. (2004) Developing distinct social models of the Internet in Latin America $(P)$ presented at the Latin American Studies Association Panel SMO0005 - October 9, 2004

United Nations. (2005). Global E-government Readiness Report - From e-government to e-inclusion. UNPAN/2005/14. 2005. New York. Disponível em: <http://unpan1.un.org/intradoc/groups/public/ documents/un/unpan021888.pdf>.

Wikipedia. (2006). "Centro Cultural" Disponível em: <http://pt.wikipedia.org/wiki/Centro_Cultural>. Acesso em: 10 Oct. 2006.

Wikipedia. (2006). "Centro Cultural São Paulo” Disponível em: <http://pt.wikipedia.org/wiki/ Centro_Cultural_S\%C3\%A3o_Paulo>. Acesso em: 10 Oct. 2006.

Wikipedia. (2006). "Creche" Disponível em: <http://pt.wikipedia.org/wiki/Creche>. Acesso em: 10 Oct. 2006.

Recebido em fevereiro de 2007

Aceito para publicação em abril de 2007 
Notes

${ }^{1}$ This paper was developed during a research fellowship at the Escola do Futuro (School of the Future) at the Universidade de Sao Paulo (University of São Paulo) - USP in Fall 2006. The group at the Escola do Futuro who hosted me was LIDEC (the Laboratório de Inclusão Digital e Educação Comunitária or Laboratory of Digital Inclusion and Community Education). Acessa São Paulo is a digital inclusion program of the Government of the State of Sao Paulo that builds, implements and maintains telecenters throughout the state, among other initiatives.

${ }^{2}$ http://www.fapesp.br/

${ }^{3}$ Instituto Brasileiro de Geografía e Estatística (Brazilian Geographic and Statistical Institute)

\section{Jeremiah Spence}

University de Texas at Austin, USA, Doctoral Student, Department of Radio, Television and Film jspence5@mail.utexas.edu

\section{Joseph Straubhaar}

University of Texas at Austin, USA, Amon G. Carter, Sr. Centennial Professor of Communication, Department of Radio, Television and Film jdstraubhaar@mail.utexas.edu 